Jurnal Bimbingan dan Konseling Ar-Rahman
Volume 7, Nomor 2, Tahun 2021
Tersedia Online: http://ojs.uniska.ac.id/index.php/BKA
e-ISSN 2477-6300

\title{
HUBUNGAN ANTARA KECERDASAN EMOSIONAL DENGAN KEMATANGAN KARIR PADA MAHASISWA SEMESTER AKHIR FAKULTAS PSIKOLOGI UNIVERSITAS DI YOGYAKARTA
}

\author{
Prayuda Nur Rifki, Laelatul Anisah \\ Universitas Selamat Sri \\ prayudapsikologi2304@gmail.com
}

\begin{abstract}
ABSTRAK
Latar belakang dari penelitian ini adalah kematangan karir yang rendah atau ketidakmatangan karir di kalangan mahasiswa, kemampuan merencanakan karir masih menjadi masalah dimana kecerdasan emosional juga dibutuhkan untuk mengatasi permasalahan-permasalahan yang dihadapai calon sarjana baru seperti kehawatiran dan ketakutan tidak mendapatkan pekerjaan, merasa kurang memiliki informasi suatu pekerjaan dan merasa tidak dapat beradaptasi dengan suatu pekerjaan. Tujuan dari penelitian ini adalah untuk mengetahui hubungan kecerdasan emosional dengan kematangan karier pada mahasiswa semester akhir Fakultas Psikologi Universitas X di Yogyakarta. Adapun metode penelitian menggunakan kuantitatif dan metode pengambilan sampel yang dipakai penelitian ini adalah teknik simple random sampling. Populasi dari penelitian ini adalah mahasiswa tingkat akhir Fakultas Psikologi Universitas X Yogyakarta. Jumlah mahasiswa semester akhir berjumlah 158 orang, sehingga jumlah sampel total penelitian 61 orang atau 71,5\% dari jumlah populasi. Hasil dari penelitian ini nilai koefisien korelasi diperoleh $\mathrm{r}=0,159$ dengan nilai $\mathrm{p}=0,000$. Nilai signifikansi sebesar 0,000 menunjukan signifikansi pada taraf $1 \%(p=0,01)$ artinya $p<0,01$. Hal ini menunjukan adanya korelasi yang sangat signifikan antara kecerdasan emosional dengan kematangan karir pada mahasiswa tingkat semester akhir Univeristas X di Yogyakarta. Hal ini berarti dengan dimilikinya kecerdasan emosional yang tinggi maka akan diikuti dengan dimilikinya kematangan karir yang tinggi juga. Begitu pula sebaliknya, dengan dimilikinya kecerdasan emosional yang rendah juga akan diikuti dengan kematangan karir yang rendah pula.
\end{abstract}

Kata Kunci: Kecerdasan Emosional; Kematangan Karir; Mahasiswa

\begin{abstract}
The background of this research is low career maturity or career immaturity among students, the ability to plan a career is still a problem where emotional intelligence is also needed to overcome the problems faced by prospective new graduates such as worries and fears of not getting a job, feeling lack of information. a job and feel unable to adapt to a job. The purpose of this study was to determine the relationship between emotional intelligence and career maturity in final semester students of the Faculty of Psychology, University $X$ in Yogyakarta. The research method uses quantitative and the sampling method used in this study is a simple random sampling technique. The population of this study were final year students of the Faculty of Psychology, University X Yogyakarta. The number of final semester students amounted to 158 people, so the total sample of the study was 61 people or $71.5 \%$ of the total population. The results of this study obtained the value of the correlation coefficient $r=0.159$ with a value of $p=0.000$. A significance value of 0.000 indicates a significance level of $1 \%(p=0.01)$ meaning $p<0.01$. This shows that there is a very significant correlation between emotional intelligence and career maturity in final semester students of University $X$ in Yogyakarta. This means that having high emotional intelligence will be followed by having high career maturity as well. Vice versa, having low emotional intelligence will also be followed by low career maturity as well.
\end{abstract}

Keywords: Emotional Intelligence; Career Maturity; College Students 


\section{PENDAHULUAN}

Dewasa merupakan salah satu tahap perkembangan yang paling penting yang dilalui oleh seorang individu, dimana sebagian besar mahasiswa adalah orang-orang yang baru menginjak tahap perkembangan dewasa awal dan baru saja meninggalkan status remajanya. Hurlock (2011) mengatakan bahwa dewasa awal dimulai pada usia 18 tahun sampai kira-kira usia 40 tahun. Perubahan yang signifikan dari tugas perkembangan remaja ke dewasa awal ini membuat idividu cukup sulit beradaptasi dengan tugas tugas perkembangan mereka yang baru.

Ditinjau dari usia pada saat mereka menempuh pendidikan di perguruan tinggi, mahaiswa tingkat akhir berada dalam tahap eksplorasi. Pada umumnya seorang mahasiswa akan menjumpai dunia kerja dan menjadi seorang tenaga kerja setelah menyelesaikan pendidikannya. Permasalahan terkait ketenagakerjaan di Indonesia belakangan ini semakin kompleks. Kurangnya lapangan pekerjaan dan persiapan perencanaan karir para mahasiswa merupakan salah satu permasalahan yang pertama kali akan ditemui oleh para mahasiswa ketikasetelah menyelesaikan pendidikannya. Selain ini Super (Muntamah dan Arianti, 2016) berpendapat bahwa sesorang yang tidak mencapai kematangan karir sesuai dengan tahapan perkembangannya dan tugas perkembangan kariernya maka akan mengalami hambatan ata bermasalah dalam kariernya. Pada tahap ini seharusnya individu sudah mulai menghubungi orang-orang yang dapat menolongnya untuk mendapatkan pekerjaan yang diminatinya, berkonsultasi dengan konselor, bahkan membuat lamaran pekerjaan serta mengikuti tes seleksi atau interview.

Bidang pekerjaan yang akan diinginkan menyebabkan mahasiswa harus menyelesaikan pendidikannya sampai taraf yang dibutuhkan oleh bidang pekerjaan yang diinginkan. Semua jenjang pendidikan perlu menyiapkan sumber daya yang berkualitas, tidak terkecuali dengan jenjang pendidikan tinggi. Sumber daya berkualitas di antaranya akan tercermin pada indeks prestasi tinggi, memiliki kematangan karir, memiliki tingkat religiusitas tinggi, serta peduli pada sesama tanpa pamrih Komalasari (Budiwati, 2012).

Berkarir di kondisi pandemi covid-19 seperti saat ini, merupakan tantangan besar bagi calon tenaga kerja seperti mahasiswa. Perkembangan kondisi ekonomi, sosial, dan budaya masyarakat yang semakin pesat mengharuskan setiap komponen dari masyarakat untuk berpacu, meningkatkan kompetensi sehingga mampu menjawab tantangan era globalisasi.
Rianto (Pinasti, 2011) mengemukakan ada beberapa tantangan yang akan dihadapi mahasiswa dalam menentukan karir, seperti ketidakpastian karir, pengaksesan informasi dan program pengembangan karir, serta tantangan-tantangan ekonomi dan teknologi.

Semakin banyaknya tantangan dan persaingan dalam dunia kerja tidak bisa dipungkiri akan menambah kecemasan mahasiswa menghadapi masa depan karinya yang pada akhirnya juga akan menambah jumlah pengangguran akademik di Indonesia. Tingginya tuntutan dunia usaha ditunjukkan melalui hasi survey yang menyebutkan bahwa $91 \%$ kalangan dunia usaha beranggapan bahwa lulusan perguruan tinggi tidak siap pakai selepas kuliah Kasih \& Suganda (Rachmawati, 2012). Permasalahan lain terkait ketenagakerjaan adalah adanya fenomena mengenai para sarjanan baru yang akan berkiprah tidak sesuai dengan bidang pendidikan yang ditempuh. Selain itu survey yang dilakukan oleh jobstreet.com (Kabarkampus, 31 Oktober 2014) diperoleh temuan bahwa sebanyak $73 \%$ karyawan merasa tidak puas dengan pekerjaannya. Ketidakpuasan karyawan tersebut disebabkan oleh beberapa faktor, salah satunya adalah ketidaksesuaian karyawan tersebut disebabkan oleh beberapa faktor, salah satunya adalah ketidaksesuaian pekerjaan dengan latar belakang pendidikan.

Ketidaksesuaian ini disebabkan oleh adanya faktor sosial yang mempengaruhi seseorang ketika ia memilih suatu pekerjaan. Hal ini dapat menciptakan ketidakpuasan seseorang akan hasil kerjanya, tidak mencintai tugasnya dan menurunnya prestasi kerja. Selain itu, terdapat banyak mahasiswa yang masih bingung tentang apa yang akan mereka kerjakan dalam hidupnya setelah tamat dari perguruan tinggi. Kondisi yang suram ini disebabkan oleh kurangnya bekal ilmu, keterampilan dan pengalaman yang dimiliki oleh seorang mahasiswa ketika ia akan memasuki dunia kerja. (Rachmawati, 2012). Data yang diperoleh dari berita resmi statistik (Badan Pusat Statistik, 2017), menyebutkan bahwa jumlah pengangguran pada Februari 2017 mencapai 7,01 juta orang atau 5,33\% dari total angkatan kerja.

Berdasarkan pada data-data di atas, peneliti melihat terkai dengan ketidaksesuaian antara latar belakang pendidikan dengan spesifikasi pekerjaan dapat menghambat aktualisasi diri dari apa yang akan dikerjakan. Artinya individu tidak dapat merealisasikan diri sesuai dengan kemampuannya yang pada akhirnya berjuang pada ketiakpuasan dalam bekerja. selain menghambat aktualisasi diri dan ketidaksesuaian latar belakang pendidikan 
dengan pekerjaan, juga dapat mengurangi produktivitas pekerjaan dan berpeluang untuk merugikan perusahaan atau tempat individu bekerja. sejalan dengan pernyataan Spencer \& Spencer (Moeheriono, 2010) yang menyebutkan bahwa kompetensi dapat memprediksi tingkah laku dan performasi secara luas pada semua situasi dan tugas pekerjaan. Hasil Penelitian oleh Abubakar (2018) juga menunjukan kompetensi, khususnya komponen pengetahuan, memberikan pengaruh positif yang sangat berarti bagi produktivitas kerja pegawai. Tingginya pengaruh komponen pengetahuan terhadap produktivitas kerja pegawai diperlihatkan berdasarkan kesesuaian latar belakang pendidikan, pengalaman kerja yang cukup, dan adanya pemahaman terhadap deskripsi pekerjaan dari pegawai (Abubakar, 2018). Artinya latar belakang pendidikan mahasiswa akhir menjadi kompetensi bagi dirinya memiliki pengaruh yang cukup besar terhadap performansi dan produktivitas dalam bekerja.

Ketika sesorang bekerja tidak sesuai dengan latar belakang pendidikannya biasanya tidak memiliki kompetensi spesifik yang mendukung pekerjaannya, sehingga dapat mengurangi performasi dan produktivitas individu dalam bekerja. Sesuai dengan pernyataan Lestari \& Raharjo (2013) mengungkapkan fenomena ketidaksesuaian pekerjaan dengan latar belakang pendidikan diakibatkan oleh para sarjana yang belum sepenuhnya mempertimbangkan minat dan bakat mereka dalam memilih pekerjaan. Mereka akan cenderung untuk memilih pekerjaan didasarkan pada rasa khawatir dan cemas bila terlalu lama menganggur, adanya rasa malu pada lingkungan apabila belum mendaptkan pekerjaan dan adanya tuntutan moral bagi orang tua.

Hal ini menunjukan kurangnya kematangan karier mahasiswa sebagi calon pekerja. Selain itu, fenomena tingginya angka pengangguran juga disebabkan karena kurangnya kematangan karir dari para calon pekerja. Hal ini di dukung oleh survey dari Willis Towers Watson yang dilakukan sejak 2014 s/d 2016 yang menyebutkan bahwa delapan dari sepuluh perusahaan di Indonesia kesulitan mendapatkan lulusan perguruan tinggi dalam negri siap pakai atau kurang siap untuk diperkerjakan (Vice, 2018). Greenbank \& Hepworth (Yusanti \& Astrini, 2015) juga menyatakan tingginya angka pengangguran adalah salah satu indicator lemahnya perencanaan karir lulusan SMA, diploma maupun sarjana. Hal ini dikarenakan kurangnya kesiapan dan perencanaan karir mahasiswa. Selain itu, Super (Muntamah \& Arianti, 2016) juga berpendapat bahwa sesorang yang tidak mencapai kematangan karir sesuai dengan tahap perkembangannya dan tugas perkembangan kariernya maka akan mengalami permasalahan dengan kariernya. Hal ini ditandai dengan kriteria seperti tidak mampu merencanakan karier dengan baik, malas melaukan eksplorasi dan kurang atau tidak memadainya pengetahuan terkait pengambil keputusan karir, tidak atau kurang memiliki pengetahuan tentang dunia kerja dan sebagainya (Muntamah \& Arianti, 2016).

Berdasarkan pemaparan diatas kurangnya kemampuan seseorang dalam hal-hal tersebut mengindikasikan kematangan karir yang rendah atau ketidakmatangan karir di kalangan mahasiswa, kemampuan merencanakan karir masih menjadi masalah. Ifdil (Pinasti, 2011) berdasarkan studinya terhadap beberapa hasil penelitian di Amerika menemukan bahwa sekitar $30 \%$ individu di sekolah menengah dan perguruan tinggi belum memutuskan pilihan karir mereka. Kondisi seperti ini ditemukan oleh peneliti berdasarkan hasil wawancara singkat yang dilakukan pada sepuluh mahasiswa Fakultas Psikologi di sebuah Perguruan Tinggi Swasta (PTS). Dari sepuluh mahasiswa yang diwawancarai oleh peneliti, sebagian besar mahasiswa masih belum memiliki perencanaan yang matang mengenai kariernya. Berdasarkan hasil wawancara dapat dilihat bahwa beberapa mahasiswa masih belum memiliki perencanaan yang cukup terkai karier dan ini merupakan salah satu ciri-ciri kematangan karir rendah, penggalian informasi mengenai pekerjaan masih jarang dilakukan dan keputusan mengenai pekerjaan apa yang akan difokuskan masih belum jelas.

Kematangan karier merupakan kesiapan dan keberhasilan individu dalam menyelesaikan tahap-tahap perkembangan karier di mana individu telah memiliki pengetahuan mendalam tentang dirinya dan pengetahuan mengenai pekerjaan yang telah dipilih, serta dapat membuat suatu keputusan dengan baik dan bertanggung jawab (Hasanah \& Rusmawati, 2018). Dewasa ini, masih banyak ditemukan sarjana yang bekerja atau berprofesi tidak sesuai dengan latar belakang pendidikannya. Selain lowongan kerja yang belum memadai dengan jumlah pencari kerja, ketidaksesuaian pekerjaan dan latar belakang pendidikannya juga dapat dipicu dari institusi-institusi, kantor-kantor, maupun lembaga-lembaga pemerintah dan swasta yang membuka lowongan pada satu posisi namun tidak mempertimbangkan latar belakang pendidikan (Pinasti, 2011). Permasalah seperti ini lah yang menyebabkan beberapa mahasiswa khawatir akan karier mereka yang nantinya akan ditempuh setelah lulus menjadi sarjana. 
Kenyataan dan keadaan yang menimbulkan kesulitan bisa dianggap sebagi tekanan, beban, atau tantangan tersendiri bagi para calon sarjana. Diperlukan suatu kecerdasan dan kualitas diri yang baik untuk menyikapi masalah-masalah tersebut, sehingga mendapat kesuksesan dalam mengambil keputusan dalam pemilihan kariernya. Karena dalam kondisi yang dimikian intelegensi saja tidaklah cukup, tetapi kecerdasan emosional juga dibutuhkan. Kecerdasan emosional juga dibutuhkan untuk mengatasi permasalahanpermasalahan yang dihadapai calon sarjana baru seperti kehawatiran dan ketakutan tidak mendapatkan pekerjaan, merasa kurang memiliki informasi suatu pekerjaan dan merasa tidak dapat beradaptasi dengan suatu pekerjaan.

Kecerdasan emosional merupakan kemampuan individu untuk mengenali, menghargai, dan menguasai emosi diri dengan tujuan agar bisa membina hubungan dengan orang lain dan bisa mengambil suatu keputusan yang tepat bagi diri sendiri (Lesatari \& Rahardjo, 2013). Individu perlu memiliki kecerdasan emosional karena kondisi emosioanl dapat mempengaruhi pikiran, perkataan, maupun perilaku, termasuk dalam pekerjaan. individu yang memiliki kecerdasan emosional akan mampu mengetahu kondisi emosionalnya dan cara mengekspresikan emosinya secara tepat sehingga emosinya dapat dikontrol dan meberikan banyak manfaat dalam kehidupan sehari-hari. Menurut Goleman (2017), kecerdasan emosional adalah kemampuan seseorang mengatur kehidupan emosinya dengan inteligensi (to manage our emotional life with intelligence); menjaga keselarasan emosi dan pengungkapannya (the appropriateness of emotion and its expression) melalui keterampilan kesadaran diri, pengendalian diri, motivasi diri, empati dan keterampilan sosial.

Alasan dipilihnya mahasiswa psikologi sebagai subjek penelitian selain karena fenomena yang peneliti temukan dan hasil dari studi awal yang telah dilakukan, juga krena psikologi adalah jurusan yang rentan mencetak pengangguran. Berdasarkan data yang diperoleh melalui sensus yang dilakukan Wall Street Journal (Puspitarini, 2011) menempatkan psikologi sebagai bidang studi yang memiliki jumlah pengangguran paling banyak dengan rinciannya sebagai berikut: psikologi klinis tingkat pengangguran lulusannya sebesar 19,5\%, psikologi industri dan organisasi dengan tingkat pengangguran 10,4\%, psikologi pendidikan dengan tingkat pengangguran $10,9 \%$, dan ragam ilmu psikologi yang mencapai $10,3 \%$.

Berdasarkan fenomena-fenomena yang telah dipaparkan diatas, peneliti memandang bahwa penelitian ini penting untuk dilakukan guna mengetahui apakah kematangan emosional berpengaruh terhadap kematangan karir. Dengan demikian, peneliti mengangkat judul Hubungan Antara Kecerdasan Emosional Dengan Kematangan Karier Mahasiswa Fakultas Psikologi Universitas X di Yogyakarta.

\section{METODE}

Berdasarkan uraian yang telah dikemukakan sebelumnya, maka hipotesis yang diajukan peneliti dalam penelitian ini adalah terdapat hubungan antara kecerdasan emosional dengan kematangan karir pada mahasiswa.

Metode penelitian yang digunakan adalah kuantitatif dengan desain penelitian korelasional. Adapun metode pengambilan sampel yang dipakai penelitian ini adalah teknik simple random sampling. Populasi dari penelitian ini adalah mahasiswa tingkat akhir Fakultas Psikologi Universitas X Yogyakarta. Adapun karakteristik populasi sebagai berikut :

a. Mahasiswa Fakultas Psikologi

b. Mahasiswa minimal semester 7 di Universitas X Yogyakarta

c. Berjenis kelamin laki-laki dan perempuan

d. Sudah menempuh masa studi minimal 3 tahun

Berdasarkan data yang diperoleh dari fakultas Psikologi diketahui bahwa jumlah mahasiswa semester akhir berjumlah 158 orang. Sehingga jumlah sampel total penelitian 61 orang atau $71,5 \%$ dari jumlah populasi Penghitungan jumlah sampel menggunakan Rumus Slovin, dalam Sugiyono (2018). Metode pengumpulan data dengan menggunakan skala kematangan karir dan skala kecerdasan emosional dengan try out terpakai. Uji validitas menggunakan teknik alpha cronbach dengan sistem output satu paket reliabilitas dengan bantuan program SPSS 20 for windows.

Uji normalitas yang digunakan dalam penelitian ini adalah uji kolmogorof-smirnov dengan menggunakan kaidah $\mathrm{p}>0,05$ maka data terditribusi normal, sebaliknya jika $\mathrm{p}<0,05$ maka data berdistribusi tidak normal (Hadi, 2012). Uji linieritas dilakukan untuk mengetahui apakah variabel bebas dan variabel terikat memiliki hubungan yang linier. Hubungan antara variabel bebas dan variabel terikat dikatakan linier jika ditemukan penyimpangan. Kaidah uji yang digunakan adalah $\mathrm{p}<0,05$ maka hubungan antara variabel bebas $(\mathrm{X})$ dan variabel terikat $(\mathrm{Y})$ dinyatakan linier dan sebaliknya jika $\mathrm{p}>0,05$ maka hubungannya tidak linier (Reksoatmodjo, 2019). Setelah terpenuhi prasyarat uji normalitas dan uji linieritas, kemudian dilakukan uji hipotesis, 
analisis data yang digunakan untuk mengetahui korelasi variabel bebas dan variabel terikat yaitu hubungan antara kematangan karir dengan kecerdasan emosional. Maka uji hipotesis menggunakan teknik analisis regresi sederhana (simple regression). Regresi sederhana digunakan apabila dalam analisis regresi jumlah variabel bebas atau prediktor hanya satu.

\section{HASIL DAN PEMBAHASAN}

\section{Uji Normalitas}

Uji normalitas dilakukan untuk mengetahui kenormalan data sebaran di dalam data penelitian, dimana yang menjadi syarat untuk dilaksanakan bahwa data tersebut normal apabila nilai data lebih dari taraf signifikan yang telah ditentukan yaitu $\mathrm{p}$ > 0,05 dengan uji Kolmogorov Smirnov. Kaidah yang digunakan untuk mengetahui normal tidaknya sebaran data adalah jika $\mathrm{p}>0,05$ maka sebaran dinyatakan normal, sebaliknya jika $\mathrm{p}<$ 0,05 maka sebaran dinyatakan tidak normal. Rangkuman hasil uji normalitas dapat dilihat pada tabel 1 berikut ini:

Tabel 1.

Hasil Uji Normalitas

\begin{tabular}{cccc}
\hline Variabel & KS-Z & P & Keterangan \\
\hline $\begin{array}{c}\text { Kematangan Karir dengan Kecerdasan } \\
\text { Emosional }\end{array}$ & 0,930 & 0,352 & Normal \\
\hline
\end{tabular}

\section{Keterangan: \\ KS-Z : Uji Kolmogorov Smirnov \\ p : Signifikansi}

Berdasarkan tabel 1 diatas, bahwa hasil dari kedua data yang diperoleh melalui alat ukur yang dibuat oleh peneliti berdistribusi normal karena memenuhi kaidah $\mathrm{p}>0,05$, dapat dilihat dari nilai p alat ukur tersebut yaitu 0,352 yang lebih besar dari 0,05 .

\section{Uji Linieritas}

Uji Linieritas merupakan uji yang dilakukan untuk mengetahui hubungan antara variabel bebas yaitu kecerdasan emosional dan variabel terikat yaitu perilaku kematangan karir. Kaidah yang digunakan adalah jika $\mathrm{p}<0,05$ berarti hubungan antara kedua variabel adalah linier, jika p > 0,05 maka hubungan antara kedua variabel tidak linier.Hasil dalam penelitian ini dapat dilihat pada tabel 2 berikut ini :

Tabel 2.

Hasil Uji Linieritas

\begin{tabular}{cccc}
\hline Variabel & F & P & Keterangan \\
\hline $\begin{array}{c}\text { Kematangan karir dengan ecerdasan } \\
\text { emosional }\end{array}$ & 3,426 & 0,001 & Linier \\
\hline
\end{tabular}

Berdasarkan tabel 2 diatas nilai $F$ merupakan koefesien yang menunjukkan hubungan antara variabel bebas dan variabel terikat $\mathrm{F}=3,426$ dan $\mathrm{p}=0,001$. Nilai $\mathrm{p}$ merupakan nilai yang menunjukkan seberapa linier hubungan antara variabel bebas dan variabel terikat. Dalam tabel di atas nilai $\mathrm{p}=0,000<0,05$ sehingga menunjukkan bahwa terdapat hubungan yang linier antara kecerdasan emosional dengan kematangan karir.

\section{Hasil Uji Hipotesis}

Metode analisis data yang digunakan untuk menguji hipotesis adalah menggunakan uji regresi sederhana yang dilakukan pada kematangan karir dan kecerdasan emosional. Hasil dalam penelitian ini dapat dilihat pada tabel 3 berikut ini :

Tabel 3.

Hasil Uji Regresi Sederhana

\begin{tabular}{ccccc}
\hline Variabel & r & R Square & P & Keterangan \\
\hline $\begin{array}{c}\text { Kematangan karir dengan } \\
\text { kecerdasan emosional }\end{array}$ & 0,159 & 0,025 & 0,000 & $\begin{array}{c}\text { Sangat } \\
\text { Signifikan }\end{array}$ \\
\hline
\end{tabular}


Berdasarkan tabel 3 di atas, diperoleh hasil nilai korelasi antara variabel kematangan karir dengan kecerdasan emosional yaitu $r=0,159$ dengan nilai $\mathrm{R}$ Square $=0,025$ dan $\mathrm{p}=0,000$ dimana $\mathrm{p}<0,01$. Ini berarti bahwa ada hubungan yang sangat signifikan antara kematangan karir dengan kecerdasan emosional pada mahasiswa. Sumbangan efektif yang diberikan oleh kematangan karir dengan kecerdasan emosional adalah sebesar 0,025 atau $25 \%$. Jadi masih terdapat $75 \%$ pengaruh dari faktor-faktor lain yang berhubungan dengan kecerdasan emosional namun tidak diteliti oleh peneliti.

Penelitian ini menggunakan teknik analisis regresi sederhana dengan uji prasyarat yang hasilnya ada penerimaan uji normalitas bahwa data variabel kematangan karir dengan kecerdasan emosional dikatakan normal karena skor $\mathrm{KS}-\mathrm{Z}=$ $0,930 \mathrm{p}=0,352$ dimana $\mathrm{p}>0,05$, selanjutnya hasil uji linieritas yang diperoleh data yang menunjukan bahwa terdapat hubungan yang linier antara kematangan karir dangen kecerdasan emosional dengan nilai $F=3,426$ dan $p=0,001$ yang lebih kecil dari 0,05. Setelah melalui analisis pengolahan data diperoleh hasil yang mendukung hipotesis tesebut. Menunjukan bahwa hipotesis tersebut terbukti melalui nilai koefisien korelasi diperoleh $\mathrm{r}$ $=0,159$ dengan nilai $\mathrm{p}=0,000$. Nilai signifikansi sebesar 0,000 menunjukan signifikansi pada taraf $1 \%(\mathrm{p}=0,01)$. artinya $\mathrm{p}<0,01$. Hal ini menunjukan adanya korelasi yang sangat signifikan antara kecerdasan emosional dengan kematangan karir pada mahasiswa tingkat semester akhir Univeristas $X$ di Yogyakarta. Hal ini berarti dengan dimilikinya kecerdasan emosional yang tinggi maka akan diikuti dengan dimilikinya kematangan karir yang tinggi juga. Begitu pula sebaliknya, dengan dimilikinya kecerdasan emosional yang rendah juga akan diikuti dengan kematangan karir yang rendah pula.

Kematangan karir adalah kesiapan individu untuk membuat keputusan karir dengan didukung oleh informasi yang kuat mengenai pekerjaan, berdasarkan eksplorasi yang telah dilakukan. Pengukuran kematangan karir diukur mengunakan skala yang dikemukan oleh Super (Sharf, 2006) yaitu: perencanaan, eksplorasi karir, pengambilan keputusan, kompetensi informasi, orientasi realita. Semakin tinggi skor mahasiswa yang diperoleh dari skala kematangan karir maka semakin tinggi pula kematangan karir sebaliknya semakin rendah skor kematangan karir yang diperoleh maka semakin rendalh pula kematangan karir. Hasil pengukuran berdasarkan variabel kematangan karir menunjukkan dari 60 mahasiswa yang dijadikan subjek penelitian terdapat 1 yang memiliki kematangan karir yang tinggi dan 43 mahasiswa yang memiliki kematangan karir yang sedang dan 16 mahasiswa yang memiliki kematangan karir rendah. Dari hasil kategori terlihat bahwa lebih banyak menujukan kematangan karir katagori sedang.

Kecerdasan emosional adalah kemampuan seseorang untuk memahami dan mengatur emosinya, memotivasi diri dan memahami emosi orang lain, sehingga dapat dimanfaatkan secara efektif dalam kehidupan sehari hari untuk membina hubungan yang baik dengan orang lain. Pengukuran kecerdasan emosional diukur menggunakan skala kecerdasan emosional yang dikemukan oleh Goleman (2001) yaitu: kesadaran diri (self awareness), mengelola emosi (management emotional), memotivasi diri (self motivating), mengenali emosi orang lain (emphaty), membina hubungan dengan orang lain (handling relationships). Semakin tinggi skor yang diperoleh dari skala kecerdasan emosional maka semakin tinggi skor yang diperoleh dari skala kecerdasan emosional semakin rendah skor kecerdasan emosional yang diperoleh maka semakin rendah pula kecerdasan emosional tersebut. Hasil pengukuran berdasarkan variabel kecerdasan emosional menunjukkan dari 60 mahasiswa yang dijadikan subjek penelitian terdapat 18 mahasiswa yang memiliki kecerdasan emosional yang tinggi dan 40 mahasiswa yang memiliki kecerdasan emosional yang sedang dan 2 mahasiswa yang memiliki kecerdasan rendah. Dari hasil kategori terlihat bahwa lebih banyak menujukan kecerdasan emosional katagori sedang.

Hasil dari penelitian ini juga diperkuat dengan hasil penelitian terdahulu yang dilakukan Lestari \& Rahardjo (2013) yang berjudul "Hubungan antara Kecerdasan Emosional dengan Kematangan Karir pada Mahasiswa Universitas Muhammadiyah Purwokerto yang sedang Menempuh Skripsi“ yang hasilnya menunjukkan bahwa dengan dimilikinya kecerdasan emosional yang tinggi maka akan diikuti dengan dimilikinya kematangan karir yang tinggi juga. Begitu pula sebaliknya dengan dimilikinya kecerdasan emosional yang rendah juga akan diikuti dengan kematangan karir yang rendah pula. Menurut Crities (Coertse \& Schepers, 2004) kematangan karir sangat penting untuk pemilihan karir seseorang. Individu yang tidak matang (immature) tidak bisa membuat pemilihan karir yang optimal.

\section{PENUTUP}


Prayuda Nur Rifki, Laelatul Anisah

Jurnal Bimbingan dan Konseling Ar-Rahman

Volume 7, Nomor 2, Tahun 2021

e-ISSN 2477-6300

Hasil dari penelitian ini nilai koefisien korelasi diperoleh $\mathrm{r}=0,159$ dengan nilai $\mathrm{p}=$ 0,000 . Nilai signifikansi sebesar 0,000 menunjukan signifikansi pada taraf $1 \%(\mathrm{p}=0,01)$. artinya $\mathrm{p}<0,01$. Hal ini menunjukan adanya korelasi yang sangat signifikan antara kecerdasan emosional dengan kematangan karir pada mahasiswa tingkat semester akhir Univeristas X di Yogyakarta. Hal ini berarti dengan dimilikinya kecerdasan emosional yang tinggi maka akan diikuti dengan dimilikinya kematangan karir yang tinggi juga. Brgitu pula sebaliknya, dengan dimilikinya kecerdasan emosional yang rendah juga akan diikuti dengan kematangan karir yang rendah pula.

Saran yang dapat dijadikan pertimbangan dalam penelitian ini diharapkan mahasiswa dapat memiliki kecerdasan emosional yang lebih tinggi sehingga mahasiswa akan mampu mencapai tingkat kematagan karir yang tinggi pula. Hal tersebut dapat dapat ditingkatkan diantaranya dengan belajar memahami dan mengontrol emosi dalam diri, selalu berfikiran positif dalam menghadapi kejadian atau situasi buruk dalam hidupnya, lebih membuka diri sehingga bisa peka dengan perasaan orang-orang disekitar serta sebisa mungkin mencoba menenagkan diri dan menghindari atau setidaknya mengurangi hal-hal yang menimbulkan stress. Adapun saran bagi peneliti selanjutnya adalah (1) agar mencermati faktor-faktor lain yang berpengaruh terhadap kematangan karir seperti kecerdasan intelektual, adversitas, spiritual serta kemampuan atau keterampilan lain yang dimiliki oleh individu, (2) dapat lebih menggali variabel yang diteliti melalui item-item pernyataan yang lebih detail dalam menggambarkan variabel serta pilihan-pilihan jawaban yang lebih sesuai dengan jenis pertanyaannya terutama pada variabel kematangan karir.

\section{REFERENSI}

Abubakar, R. R. (2018). Pengaruh kompetensi pegawai terhadap produktivitas kerja pegawai dinas kesehatan kota Bandung, Jurnal Administrasi Negara, 24 (1), 17-32.

Anggraeni, W. P. (2015). Analisis pengaruh kecerdasan emosional terhadap kepercayaan karir individu pada wanita yang memiliki konflik peran ganda. Calyptra, 4 (1).

Arikunto, S. (2010). Prosedur Penelitian Suatu Pendekatan Praktik. Jakarta: Rineka Cipta.

Ariyanti, S. L. (2017). Hubungan Forgiveness dan Kecerdasan Emosi dengan Psychological Well-Being pada Mahasiswa. Skripsi.
Azwar, S. (2012). Reliabilitas dan Validitas. Yogyakarta: Pustaka Pelajar.

Budiwati, H. (2012). Implementasi Marketing Mix Dan Pengaruhnya Terhadap Keputusan Pembelian Konsumen Pada Produk Unggulan Keripik Pisang Agung Di Kabupaten Lumajang. Jurnal WIGA, 2(2).

Di Fabio, A., \& Kenny, M. E. (2011). Promoting emotional intelligence and career decision making among Italian high school students. Journal of Career Assessment, 19, 21-34.

Goleman, D. (2017). Kecerdasan Emosi (ed ke-3). PT. Gramedia Pustaka Utama. Jakarta.

Hasanah, N., \& Rusmawati , D. (2018). Hubungan Antara Resiliensi Dengan Kematangan Karir Pada Remaja Penyandang Disabilitas Daksa Prof. Dr. Soeharso Surakarta. Jurnal Empati, 7(3), 289.

Hurlock, E. B. (2011). Developmental Psychology. 3rd Ed, New Delhi: McGraw Hill, Inc.

Ifdil. (2010). Bimbingan karier di perguruan tinggi. Jurnal Bimbingan dan Konseling Indonesia, Diambil dari http://konselingindonesia.com pada tanggal 20 April 2011.

Lestari, T. N., \& Rahardjo, P. (2013). Hubungan Antara kecerdasan emosional dengan kematangan karier pada mahasiswa Universitas Muhammadiyah Purwokerto yang sedang menempuh Skripsi. $P S Y C H O$ IDEA.

Moeheriono. (2010). Pengukuran Kinerja Berbasis Kompetensi. Surabaya: Ghalia Indonesia.

Notoatmodjo, S. (2010). Metodologi Penelitian Kesehatan. Jakarta : Rineka Cipta.

Pinasti, W. (2011). "Pengaruh Self Efficacy, Locus Of Control dan Faktor Demografis Terhadap Kematangan Karir Mahasiswa UIN Syarif Hidayatullah Jakarta”. Skripsi pada Fakultas Psikologi, Universitas Islam Negeri Syarif Hidayatullah Jakarta.

Rachmawati, Y. E. (2012). Hubungan antara self efikasi dengan karir pada mahasiswa tingkat awal dan tingkat akhir di Universitas Surabaya. Calyptra: Jurnal Ilmiah Mahasiswa Universitas Surabaya, 1 (1).

Reksoatmodjo. (2009). Statistika Eksperimen Rekayasa. Bandung: PT Refika Aditama.

Saam, \&. Mulyani S. (2012). Psikologi Keperawatan. Jakarta: PT Raja Grafindo Persada.

Seal \& Andrews-Brown, C. R. (2010). An Integrative model of emotional intelegence : emotional ability as a 
Prayuda Nur Rifki, Laelatul Anisah

Jurnal Bimbingan dan Konseling Ar-Rahman

Volume 7, Nomor 2, Tahun 2021

e-ISSN 2477-6300

moderator of the mediated relationship of emotional quotient and emotional competence. Organizational Management Journal, 143-152.

Sugiyono. (2012). Metode Penelitian Kuantitatif Kualitatif dan $R \& B$. Bandung: Alfabeta.

Sujarweni, V. Wiratna. (2014). Metode Penelitian: Lengkap, Praktis, dan Mudah Dipahami. Yogyakarta: Pustaka Baru Press.

Sumiyarsih W, Mujiasih E, Ariati, J. (2012) Hubungan antara kecerdasan emosional dengan organizational citizenship behavior (OCB) pada karyawan CV. Aneka Ilmu Semarang. Jurnal Psikologi Undip, 11(1).

Tekke, M., \& Ghani, M.F.A. (2013). Examining The Level of Career Maturity Among Asian Foreign Students in a Public University: Gender And Academic Achievement. Hope Journal of Research. House of Pakistani Educationists, 1(1).

Widhianingrum, P. (2017). The influence of intellectual intelligence, emotional intelligence, and spiritual intelligence on understanding magnitude of behavioral accounting. Journal of Accounting an Bussiness Education, 1 (2), 191-207.

Yamin, S., \& Kurniawan, H. (2014). SPSS Complete: Teknik Analisis Terlengkap dengan Software SPSS. Jakarta: Salemba Infotek.

Zulkaida, D. (2007). Pengaruh locus of control dan efikasi diri terhadap kematangan karir siswa Sekolah Menengah Atas (SMA). Proceeding PESAT (Psikologi, Ekonomi, Sasatra, Arsitek, \& Sipil), Vol.2. 